Article

\title{
An Experimental Study on Flexural Behaviors of Reinforced Concrete Member Replaced Heavyweight Waste Glass as Fine Aggregate under Cyclic Loading
}

\author{
So Yeong Choi ${ }^{1}$, Yoon Suk Choi ${ }^{2}$ (D) Il Sun Kim ${ }^{1}$ and Eun Ik Yang ${ }^{1, *(1)}$ \\ 1 Department of Civil Engineering, Gangneung-Wonju National University, Jukheon-gil 7, Gangneung-si, \\ Gangwon-do 25457, Korea; csy7510@gwnu.ac.kr (S.Y.C.); iskim@gwnu.ac.kr (I.S.K.) \\ 2 Convergence Technology Division, Korea Conformity Laboratories, Seoul 08503, Korea; yoons0305@kcl.re.kr \\ * Correspondence: eiyang@gwnu.ac.kr; Tel.: +82-33-640-2418
}

Received: 27 September 2018; Accepted: 7 November 2018; Published: 9 November 2018

\begin{abstract}
The development of electronic technology has accelerated in recent decades. Consequently, electronic wastes such as cathode ray tube (CRT) glass are accumulated, and hazardous wastes including heavy metals are generated. Simultaneously, natural resources are required to create concrete; however, they are already exhausted. Furthermore, heavyweight waste glass is considered to be the most suitable substitute for aggregate owing to its physical characteristics and chemical composition. However, structural results regarding the recycling of heavyweight waste glass as fine aggregate in Reinforced Concrete (RC) members are insufficient. Thus, herein, experimental study is conducted to evaluate whether RC members with heavyweight waste glass as fine aggregate can be applied for concrete structures. Flexural behavior tests of reinforced concrete members were performed. Fifteen specimens with different substitution ratios of heavyweight waste glass were prepared. The results showed that when all the fine aggregate is replaced by heavyweight waste glass in RC members, the heavyweight waste glass substitution ratio affected the crack occurrence patterns, and the possibility of a sudden failure of a member increased owing to concrete crushing in the compression zone. Additionally, the load capacity and flexural rigidity were affected by the substitution ratio of heavyweight waste glass; however, the flexural performance is improved when mineral admixture as a binder or a low water-binder ratio were used. Therefore, heavyweight waste glass is considered applicable for use as fine aggregate of concrete.
\end{abstract}

Keywords: flexural behavior; recycling; heavyweight waste glass; cyclic load; reinforced concrete member

\section{Introduction}

Concrete is the primary material in construction worldwide. Additionally, the need for concrete will increase to almost 7.5 billion $\mathrm{m}^{3}$ (approximately 18 billion ton) a year by 2050 [1,2]. Particularly, the rapid development on large-scale infrastructures is causing the exhaustion of natural resources; several countries are facing the shortage of natural resources and the supply of aggregates is being exhausted [1]. Therefore, those countries are relying on imports to satisfy their needs. To handle this situation, a variety of studies are performed for the development of alternative resources for concrete [3-5]. Meanwhile, the recycling technologies of electric waste have been emphasized as a global issue, owing to its rapidly growing volume and complex nature [6]. Additionally, since 2012, when analog TV broadcasting ended, systems were converted to digital TV broadcasting in South Korea, and a large volume of cathode-ray tube (CRT) TVs and monitors were discarded. CRT glass products are classified into panels and funnels, wherein the panels may be reused as 
glass after washing; however, it is difficult to treat the funnels (heavyweight waste glass) using conventional recycling technology because they contain many heavy metals such as iron and lead $[7,8]$. Therefore, heavyweight waste glass has been studied extensively for many years. Conventionally, it is produced with crushed concrete materials. Using heavyweight waste glass as fine aggregate in concrete demonstrated some benefits such as improved durability $[9,10]$.

Meanwhile, almost all other studies focused on the removal of heavy metal in heavyweight waste glass. However, in our previous studies, we demonstrated the applicability of crushed heavyweight waste glass as fine aggregate in shielding concrete [11,12]. The results of those studies in indicated that, to improve the shielding performance, it is important to increase the density of the material in the radiation shielding concrete. Therefore, we did not perform any treatment to remove the heavy metals. Furthermore, we investigated the effect of heavyweight waste glass on the volume change properties of mortar according to the substitution ratio. The result indicated that it may be feasible to utilize heavyweight waste glass as fine aggregate in mortar specimens [1].

Additionally, previous experimental studies have focused primarily on the mechanical properties or durability of concrete or mortar specimens [9,13-16]. Hitherto, structural behavior investigations are rarely conducted in RC members that use recycled heavyweight waste glass as fine aggregate. Namely, structural results regarding recycling heavyweight waste glass as fine aggregate are insufficient. Particularly, few have been investigated under the cyclic loading condition. The objective of this paper is to investigate experimentally the flexural behavior of RC members under cyclic loading, and the effect of the heavyweight waste glass substitution ratio.

\section{Materials and Methods}

\subsection{Materials}

In this study, Ordinary Portland Cement (OPC) was used in all the RC members. To investigate the effect of mineral admixtures on the flexural behavior of RC members, the cement part was replaced with a mineral admixture at a water-binder ratio of $45 \%$. The mineral admixture type was Fly Ash (FA) and Blast Furnace Slag (BFS). The physical and chemical compositions of the binders are shown in Table 1.

Table 1. Physical and chemical compositions of the binders.

\begin{tabular}{|c|c|c|c|c|}
\hline \multicolumn{5}{|c|}{ Binders Properties } \\
\hline \multirow{2}{*}{ Physical } & Specific gravity & 3.15 & 2.34 & 2.82 \\
\hline & Blaine $\left(\mathrm{cm}^{2} / \mathrm{g}\right)$ & 3200 & 3700 & 4000 \\
\hline \multirow{7}{*}{ Chemical (\%) } & $\mathrm{SiO}_{2}$ & 21.36 & 52.83 & 31.85 \\
\hline & $\mathrm{Al}_{2} \mathrm{O}_{3}$ & 5.03 & 18.08 & 14.55 \\
\hline & $\mathrm{Fe}_{2} \mathrm{O}_{3}$ & 3.31 & 7.74 & 0.59 \\
\hline & $\mathrm{CaO}$ & 63.18 & 5.95 & 34.95 \\
\hline & $\mathrm{MgO}$ & 2.89 & 1.43 & 5.63 \\
\hline & $\mathrm{SO}_{3}$ & 2.30 & 0.01 & 2.97 \\
\hline & LOI & 1.40 & 6.14 & 0.60 \\
\hline
\end{tabular}

Crushed gravel was used as coarse aggregate with the maximum aggregate size, $\mathrm{G}_{\max }$ of $20 \mathrm{~mm}$. The specific gravity and absorption ratio of the coarse aggregate were $2.68 \%$ and $1.35 \%$, respectively. River sand having a fineness modulus of 2.79 was used as a natural fine aggregate in the RC member. The specific gravity and absorption ratio of this fine aggregate were $2.6 \%$ and $1.07 \%$, respectively. Furthermore, crushed heavyweight waste glass was used as fine aggregate. 


\subsection{Heavywegiht Waste Glass}

The heavyweight waste glass was supplied from the TV funnel or cathode-ray tube, and it was crushed by a jaw crusher for use as fine aggregate in concrete [12]. Only crushed heavyweight waste glass that could pass through a No. 4 sieve was used. Heavyweight waste glass has a specific gravity of 3.0 and fineness modulus of 3.34, respectively. To determine the fineness modulus of heavyweight waste glass, we used sieve of No. 4, No. 8, No. 16, No. 30, No. 50, and No. 100 according to ASTM C 136 [17]. The physical and chemical compositions of the heavyweight waste glass are shown in Table 2, as determined using X-ray fluorescence. Furthermore, Type 1-4 refers to different manufactures and size of television. These are composed of heavy metals such as iron, lead, and chromium, regardless of the manufacturer and size of the television.

Table 2. Physical and chemical compositions of heavyweight waste glass.

\begin{tabular}{ccccccc}
\hline \multirow{2}{*}{ Properties } & Products & Type 1 & Type 2 & Type 3 & Type 4 & \multirow{2}{*}{ Avg. } \\
\hline \multirow{2}{*}{ Physical } & & \multicolumn{5}{c}{3.0} \\
& \multicolumn{2}{c}{ Specific gravity } & & 3.34 & \\
\cline { 2 - 7 } & F.M. & 49.9 & 40.3 & 40.3 & 42.0 & 43.1 \\
\cline { 2 - 7 } & $\mathrm{Fe}_{2} \mathrm{O}_{3}$ & 15.1 & 12.7 & 12.7 & 12.8 & 13.3 \\
\cline { 2 - 7 } Chemical (\%) & $\mathrm{PbO}^{*} \mathrm{Cr}_{2} \mathrm{O}_{3}$ & 16.7 & 14.4 & 14.4 & 14.4 & 15.0 \\
\cline { 2 - 7 } & $\mathrm{SiO}_{2}$ & 9.6 & 20.4 & 20.4 & 18.7 & 17.3 \\
\cline { 2 - 7 } & $\mathrm{K}_{2} \mathrm{O}$ & 1.8 & 2.8 & 2.7 & 2.6 & 2.5 \\
\cline { 2 - 7 } & $\mathrm{Other}$ & 6.8 & 9.4 & 9.5 & 9.5 & 8.8 \\
\hline
\end{tabular}

\subsection{Test Variables and Mix Proportions}

To investigate the flexural behaviors with the heavyweight waste glass substitution ratio, we performed a compressive strength test on the concrete specimens, and a flexural test on the RC members. The test variables are listed in Table 3.

Table 3. Test variables.

\begin{tabular}{cc}
\hline Item & Contents \\
\hline W / B ratio & $35 \%, 45 \%, 55 \%$ \\
Mineral admixture (replacement ratio) & FA $(20 \%), \mathrm{BFS}(50 \%)($ at W $/ \mathrm{B} 45 \%)$ \\
Waste glass substitution ratio & $0,50,100(\%)$ \\
Age (testing days) & $28(35 \mathrm{OPC}, 45 \mathrm{OPC}, 55 \mathrm{OPC})$ \\
& $91(45 \mathrm{FA} 20,45 \mathrm{BFS} 50)$ \\
Specimen size $(\mathrm{mm})$ & $150 \times 205 \times 1400 \mathrm{~mm}(\mathrm{RC}$ member $)$ \\
& $\varnothing 100 \times 200 \mathrm{~mm}($ Compressive strength $)$ \\
\hline
\end{tabular}

In this study, the water-to-binder ratios of the specimen were varied at $\mathrm{W} / \mathrm{B} 35 \%$ (i.e., 35OPC), $\mathrm{W} / \mathrm{B} 45 \%$ (i.e., $45 \mathrm{OPC}$ ) and $\mathrm{W} / \mathrm{B} 55 \%$ (i.e., $55 \mathrm{OPC}$ ) for the evaluation of the properties of the RC member. The heavyweight waste glass was used as a substitute for fine aggregate at $0 \%, 50 \%$ and $100 \%$ by volume. In addition, to investigate the effects of mineral admixture on the RC members, the cement part was replaced by a mineral admixture at a $\mathrm{W} / \mathrm{B}$ ratio of $45 \%$. The replacement ratios were $20 \%$, for FA (i.e., 45FA20), and 50\% for BFS (i.e., 45BFS50). The flexural test for the OPC case was conducted at 28 days; meanwhile, the FA and BFS case was conducted at 91 days obtain to the sufficient reaction of mineral admixture. The concrete mixture proportions with the heavyweight waste glass substitution ratio for all test members are listed in Table 4. The target slump and air content values of concrete were $100 \pm 20 \mathrm{~mm}$ and $4.5 \pm 1.0 \%$, respectively. 
Table 4. Concrete mix proportion.

\begin{tabular}{|c|c|c|c|c|c|c|c|c|c|}
\hline \multirow{2}{*}{ Specimen ID } & \multirow{2}{*}{ W/B (\%) } & \multirow{2}{*}{ H.R ${ }^{1}$} & \multicolumn{7}{|c|}{ Unit Weight $\left(\mathrm{kg} / \mathrm{m}^{3}\right)$} \\
\hline & & & $\mathbf{W}$ & $\mathrm{C}$ & G & $S$ & H.G ${ }^{2}$ & FA & BFS \\
\hline $35 \mathrm{OPC}-0$ & 35 & 0 & 167 & 477 & 999 & 673 & - & - & - \\
\hline 35OPC-50 & 35 & 50 & 167 & 477 & 999 & 337 & 388 & - & - \\
\hline $35 \mathrm{OPC}-100$ & 35 & 100 & 167 & 477 & 999 & - & 777 & - & - \\
\hline $45 \mathrm{OPC}-0$ & 45 & 0 & 170 & 378 & 1008 & 738 & - & - & - \\
\hline $45 \mathrm{OPC}-50$ & 45 & 50 & 170 & 378 & 1008 & 369 & 426 & - & - \\
\hline 45OPC-100 & 45 & 100 & 170 & 378 & 1008 & - & 851 & - & - \\
\hline $55 \mathrm{OPC}-0$ & 55 & 0 & 173 & 315 & 998 & 792 & - & - & - \\
\hline 55OPC-50 & 55 & 50 & 173 & 315 & 998 & 396 & 457 & - & - \\
\hline $55 \mathrm{OPC}-100$ & 55 & 100 & 173 & 315 & 998 & - & 914 & - & - \\
\hline 45FA20-0 & 45 & 0 & 170 & 302 & 996 & 729 & - & 76 & - \\
\hline 45FA20-50 & 45 & 50 & 170 & 302 & 996 & 364 & 420 & 76 & - \\
\hline 45FA20-100 & 45 & 100 & 170 & 302 & 996 & - & 841 & 76 & - \\
\hline 45BFS50-0 & 45 & 0 & 170 & 189 & 971 & 713 & - & - & 189 \\
\hline 45BFS50-50 & 45 & 50 & 170 & 189 & 971 & 357 & 421 & - & 189 \\
\hline 45BFS50-100 & 45 & 100 & 170 & 189 & 971 & - & 842 & - & 189 \\
\hline
\end{tabular}

${ }^{1}$ Heavyweight waste glass substitution ratio. ${ }^{2}$ Heavyweight waste glass.

\subsection{Test Method}

\subsubsection{Experimental Set-Up for Compressive Strength}

For the compressive strength tests, the specimens $(\varnothing 100 \mathrm{~mm} \times 200 \mathrm{~mm}$ ) were prepared based on ASTM C 39 [18]. The compressive load was supplied by a universal testing machine (UTM) with a capacity of $1000 \mathrm{kN}$. Each compressive strength value was the average of three specimens. Moreover, for the calculation of the elastic modulus, the linear variable displacement transducer (LVDT) was attached on the opposite side of the cylindrical specimen at a mid-height level (measuring distance = $100 \mathrm{~mm}$ ) and the displacement value was obtained from the LVDT. The elastic modulus was calculated from the stress-strain relationship obtained at each step. The modulus of elasticity of ASTM C 469 [19] was calculated.

\subsubsection{Experimental Set-Up for Flexural Behavior}

$\mathrm{RC}$ members were prepared to investigate the effect of the substitution ratio of heavyweight waste glass on the flexural behavior. The size of the RC member for the flexural test is $150 \mathrm{~mm} \times 205 \mathrm{~mm} \times$ $1400 \mathrm{~mm}$ (width $\times$ depth $\times$ length). All RC members were loaded at two points symmetrically about the center section. Cyclically increasing displacement loading was applied on beams and the total load applied by the hydraulic jack was measured with a $500 \mathrm{kN}$ capacity load cell. A load spreader beam was used to distribute the total load at two loading points such that a constant moment region of length $400 \mathrm{~mm}$ was obtained. The details related to the test set up are shown in Figure 1.
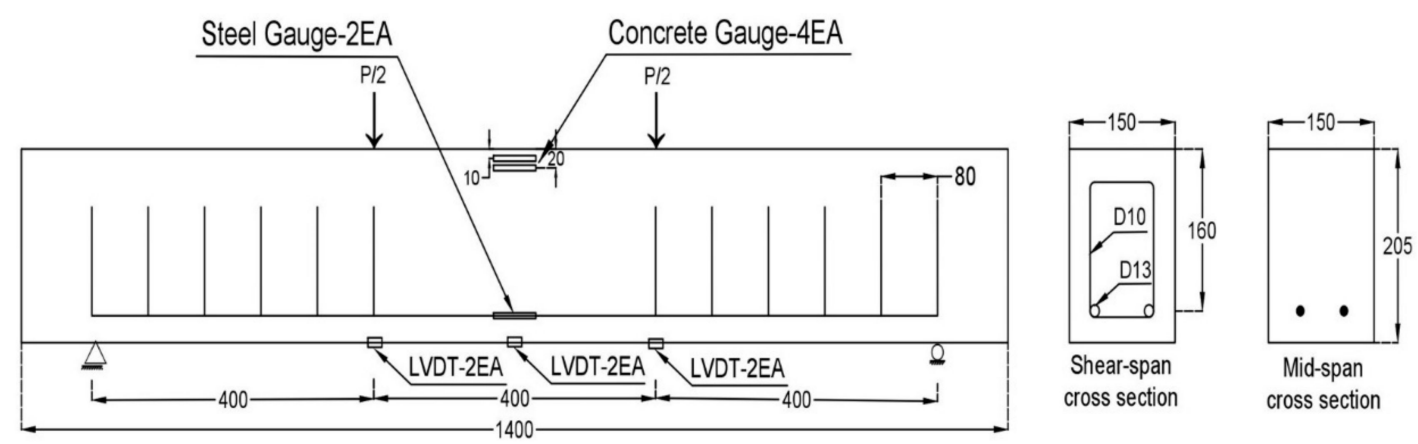

Figure 1. Reinforcement detail and cross-section of the RC member. 
Meanwhile, the mechanical properties of the reinforcement used in this study are shown in Table 5. The nominal diameter of the primary reinforcement is $13 \mathrm{~mm}$ and the yield strength $\left(\mathrm{f}_{\mathrm{y}}\right)$ is $430 \mathrm{MPa}$. The yield strength of the stirrups with a diameter of $10 \mathrm{~mm}$ is $480 \mathrm{MPa}$. The stirrup spacing is $80 \mathrm{~mm}$.

Table 5. Mechanical properties of reinforcement used in RC member.

\begin{tabular}{ccc}
\hline Diameter & Elastic Modulus (GPa) & Yield Stress (MPa) \\
\hline D 13 & 200 & 430 \\
D 10 & 200 & 480 \\
\hline
\end{tabular}

When the central displacement at the center of a member reached $0.5 \Delta y, 1.0 \Delta y, 2.0 \Delta y, 3.0 \Delta y$ and $4.0 \Delta \mathrm{y}$, the vertical load was removed and reapplied cyclically, where $\Delta \mathrm{y}$ is the yielding displacement of the member as obtained from the load-displacement curve (Figure 2).

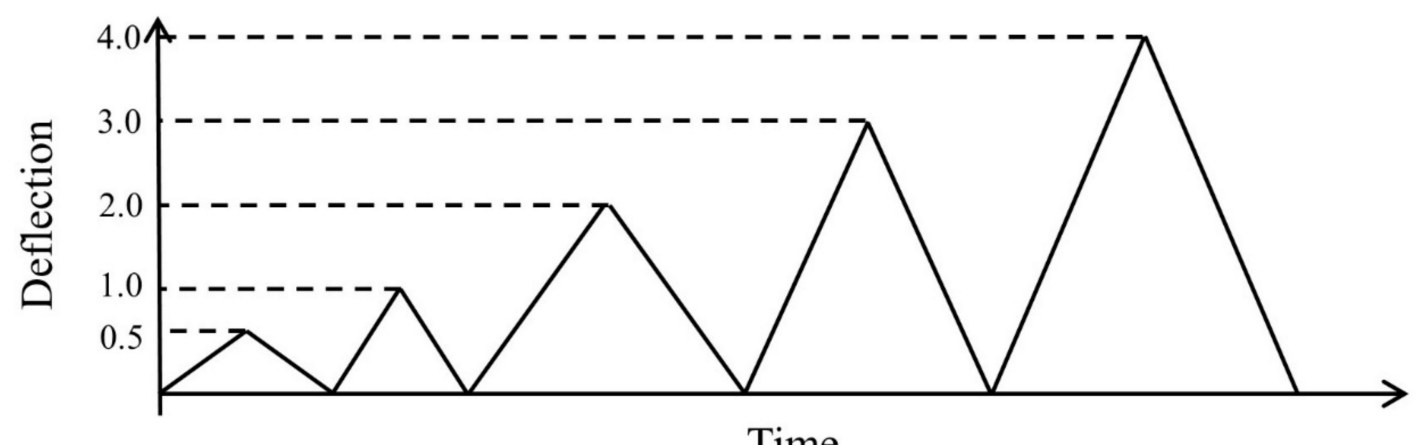

Figure 2. Schemed applied cyclic loading history.

To obtain the vertical displacement under an increasing load, an LVDT was installed vertically on the bottom of the center section. In addition, the steel strain at each stage was measured using a steel strain gauge. To obtain the concrete strain at the compressive zone, the strain gauge of concrete was attached to the $10 \mathrm{~mm}$, and $20 \mathrm{~mm}$ lines from the edge of the compressive zone.

\section{Results and Discussion}

\subsection{Effect of Heavyweight Waste Glass on Compression Properties of Concrete}

Prior to the flexural test of the RC members, an experiment was conducted to evaluate the compression properties of the concrete specimens. The test results of the compressive strength and elastic modulus of the concrete specimens replaced heavyweight waste glass are presented in Figure 3. Likewise, results of previous studies $[11,12,20,21]$ indicated that the compressive strength increased with decreased water-binder ratio, and the use of mineral admixture, regardless of the heavyweight waste glass substitution ratio. However, when the fine aggregate was replaced by heavyweight waste glass in concrete, the compressive strength decreased, whereas it decreased by approximately $9.8-28 \%$ as compared to the $0 \%$ substitution case. Namely, when the heavyweight waste glass substitution ratio increased, the compressive strength decreased. This phenomenon is most likely due to the poorer adhesion between the smooth surface of the glass and the cement past [11,22]. Furthermore, the elastic modulus decreased with increased of substitution ratio of heavyweight waste glass. As such, the elastic modulus was determined based on the compressive strength.

Meanwhile, the compressive strength and elastic modulus of the 45FA20 and 45BFS50 case specimens demonstrated better results than the 45OPC case at 91 days. The mineral admixture could be attributed to the pozzolanic reaction at a later ages.

In general, the compressive strength of normal concrete (OPC) increases with age. Particularly, the influence of water content on concrete strength is obvious; however, sealed curing was executed 
for RC members in this study. Owing to the difference between previous research [20] and the cuing condition of this study, therefore, the increment in the compressive strength of the OPC case was little after 28 days curing period.
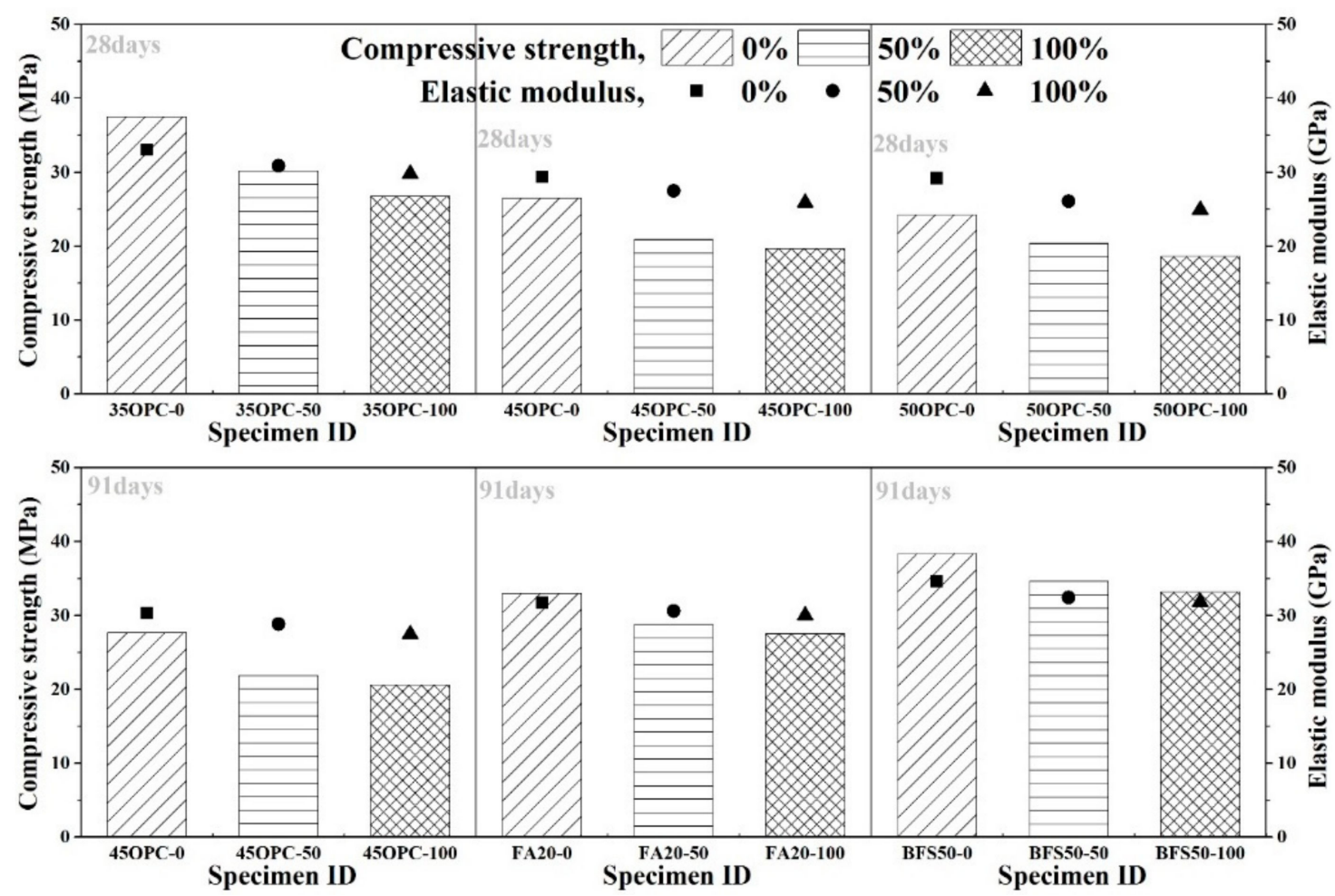

Figure 3. Compression properties of concrete specimen.

\subsection{The Effect of Heavyweight Waste Glass on Cracking of Concrete}

\subsubsection{Crack Pattern}

To evaluate the crack pattern, a crack map was drawn during the flexural test at different load levels. The Figure 4 shows a typical crack occurrence pattern in this test. From the results, all RC members began with the appearance of flexural cracks after the crack opening at the bottom of the center of the RC member, which grew vertically, regardless of the $\mathrm{W} / \mathrm{B}$ ratios and substitution ratios. Furthermore, the initial flexural cracks were developed in the pure bending zone; as the load increased gradually, the shear-flexural crack appeared. The flexural cracks are extended in the vicinity of the pure bending zone and the failure of the RC members occurred owing to concrete crushing in the compression zone.
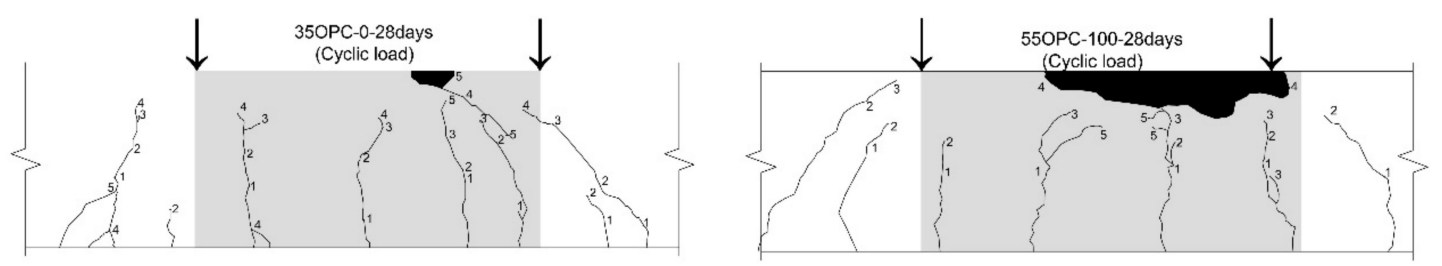

Figure 4. Cont. 

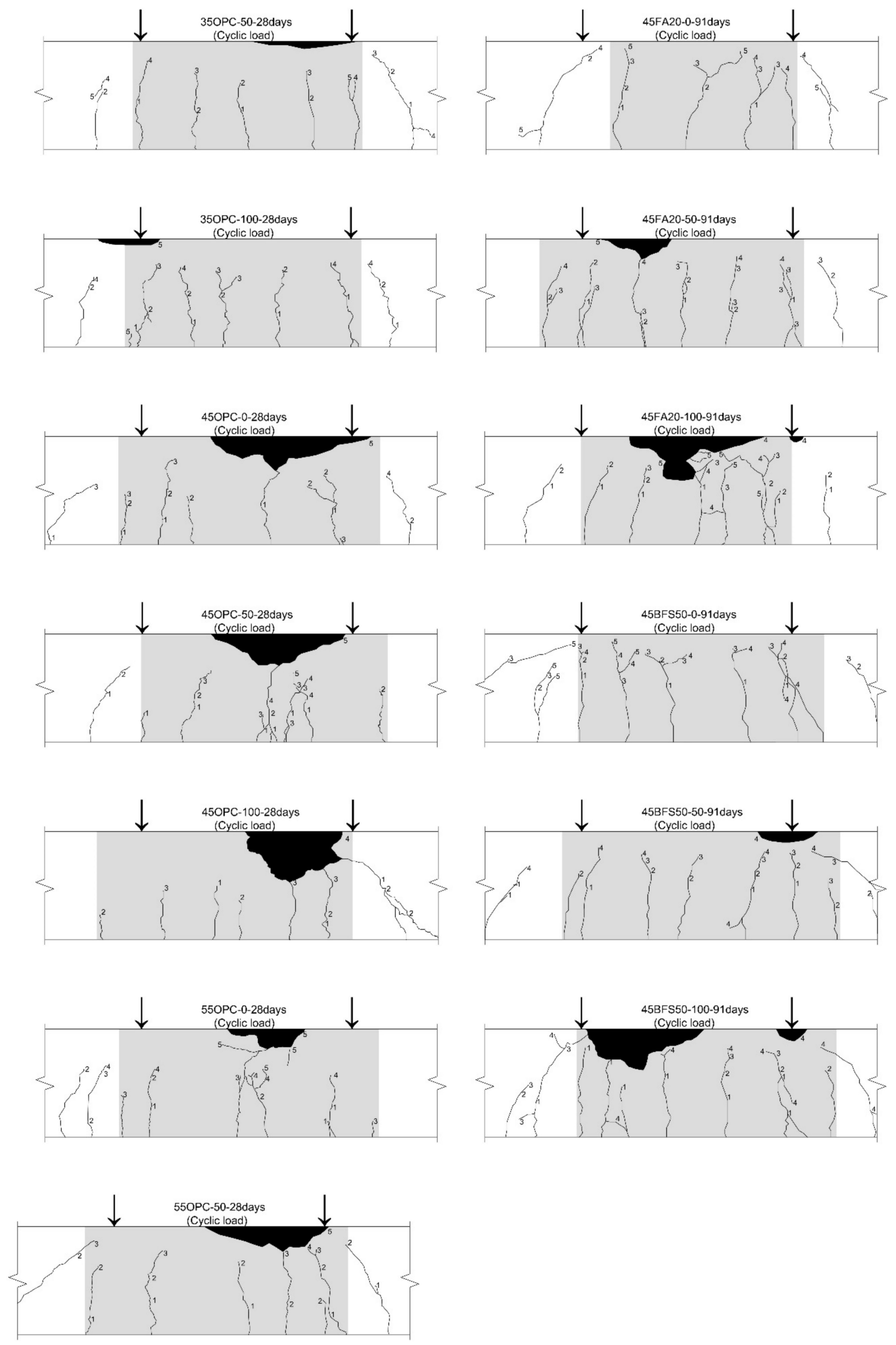

Figure 4. Typical crack occurrence pattern. 


\subsubsection{Crack Number and Failure Mode}

Table 6 shows the number of cracks, mean cracking spacing, and area of compressive crushing determined in the vicinity of the pure bending zone. According to the test results, when the heavyweight waste glass substitution ratio increased, the area of the compressive crushing increased; however, the mean cracking spacing decreased. This is because the compressive strength decreased as the heavyweight waste glass substitution ratio increase. However, 45FA20, $45 \mathrm{BFS} 50$ case demonstrated less crushing by the addition of admixture. Meanwhile, W/B 55\% case demonstrated the different results. The W/B 55\% case exhibits a low compressive strength; therefore, the number of cracks decreased and the mean crack spacing increased with heavyweight waste glass substitution. The area of compression crushing in the RC member contributed to the lower bond strength between the concrete replaced heavyweight waste glass as fine aggregate and rebar compared with that of non-substituted concrete. Therefore, the bond strength influenced crack propagation in the RC member.

Table 6. Results of experimental test for RC member (Crack).

\begin{tabular}{|c|c|c|c|c|c|c|c|c|c|}
\hline \multirow{2}{*}{$\begin{array}{c}\text { Specimen ID } \\
\text { H.R }\end{array}$} & \multicolumn{3}{|c|}{$35 \mathrm{OPC}$} & \multicolumn{3}{|c|}{$45 \mathrm{OPC}$} & \multicolumn{3}{|c|}{$55 \mathrm{OPC}$} \\
\hline & 0 & 50 & 100 & 0 & 50 & 100 & 0 & 50 & 100 \\
\hline Number of cracks (ea) & 5 & 5 & 7 & 5 & 6 & 6 & 7 & 6 & 4 \\
\hline $\begin{array}{l}\text { Mean. crack spacing } \\
(\mathrm{mm})\end{array}$ & 101.69 & 101.46 & 84.27 & 103.85 & 92.67 & 85.31 & 79.11 & 98.99 & 134.15 \\
\hline $\begin{array}{l}\text { Area of compression } \\
\text { crushing }\left(\mathrm{mm}^{2}\right)\end{array}$ & 710.6 & 1447.2 & 1120.7 & 9450.2 & 8668.7 & $11,988.7$ & 3167.1 & 6250.3 & 9214.2 \\
\hline Specimen ID & & 45FA20 & & & 45BFS50 & & & & \\
\hline H.R & 0 & 50 & 100 & 0 & 50 & 100 & & & \\
\hline Number of cracks (ea) & 4 & 7 & 6 & 6 & 7 & 7 & & & \\
\hline $\begin{array}{l}\text { Mean. crack spacing } \\
(\mathrm{mm})\end{array}$ & 108.57 & 81.18 & 71.91 & 90.54 & 86.51 & 79.73 & & & \\
\hline $\begin{array}{l}\text { Area of compression } \\
\text { crushing }\left(\mathrm{mm}^{2}\right)\end{array}$ & - & 2488.6 & 8917.2 & - & 1761.5 & 10521.2 & & & \\
\hline
\end{tabular}

\subsection{Load-Displacement Relationship}

The displacement of the RC member was measured at each load levels by the LVDT installed at the center of the RC member. The load-displacement curves of the RC members are shown in Figure 5. Furthermore, Table 7 shows the initial cracking load, yielding load, peak load, and displacement for each specimen.

The initial cracking load could be specified at the end point of the linear relationship between the load and relative displacement of the RC members. Furthermore, the yielding load is determined from the reading values of the strain gauges placed on the reinforcing rebar at mid-span. The peak load is the maximum load of the load-displacement curve. As shown in Figure 5 and Table 7, the initial crack load was the largest for the 35OPC- 0 case, and it was affected by the water-binder ratio and heavyweight waste substitution ratio.

In general, the yield point depends on the tensile capacity of the reinforcement. The yielding load is considered to be similar regardless of the heavyweight waste glass substitution ratio. However, the yield point is changed slightly, and there was no trend. Therefore, the structural test error was included. Meanwhile, the maximum load of the RC member was affected by the heavyweight waste glass substitution ratio. The load capacity of the RC member was reduced gradually on the large deformed stage when all the fine aggregate was replaced by heavyweight waste glass.

Particularly, the 55OPC case exhibited a relatively low strength than other W/B ratios; therefore, even if the heavyweight waste glass is substituted with only $50 \%$ of the fine aggregate, the load capacity 
is reduced. The mineral admixture, however, improved the load capacity of the RC member substituted heavyweight waste glass as all the fine aggregate. The load-displacement curves of the RC members were affected by the heavyweight waste glass substitution ratio. However, the effect of heavyweight waste glass could be reduced using a relatively low water-binder ratio or mineral admixture.

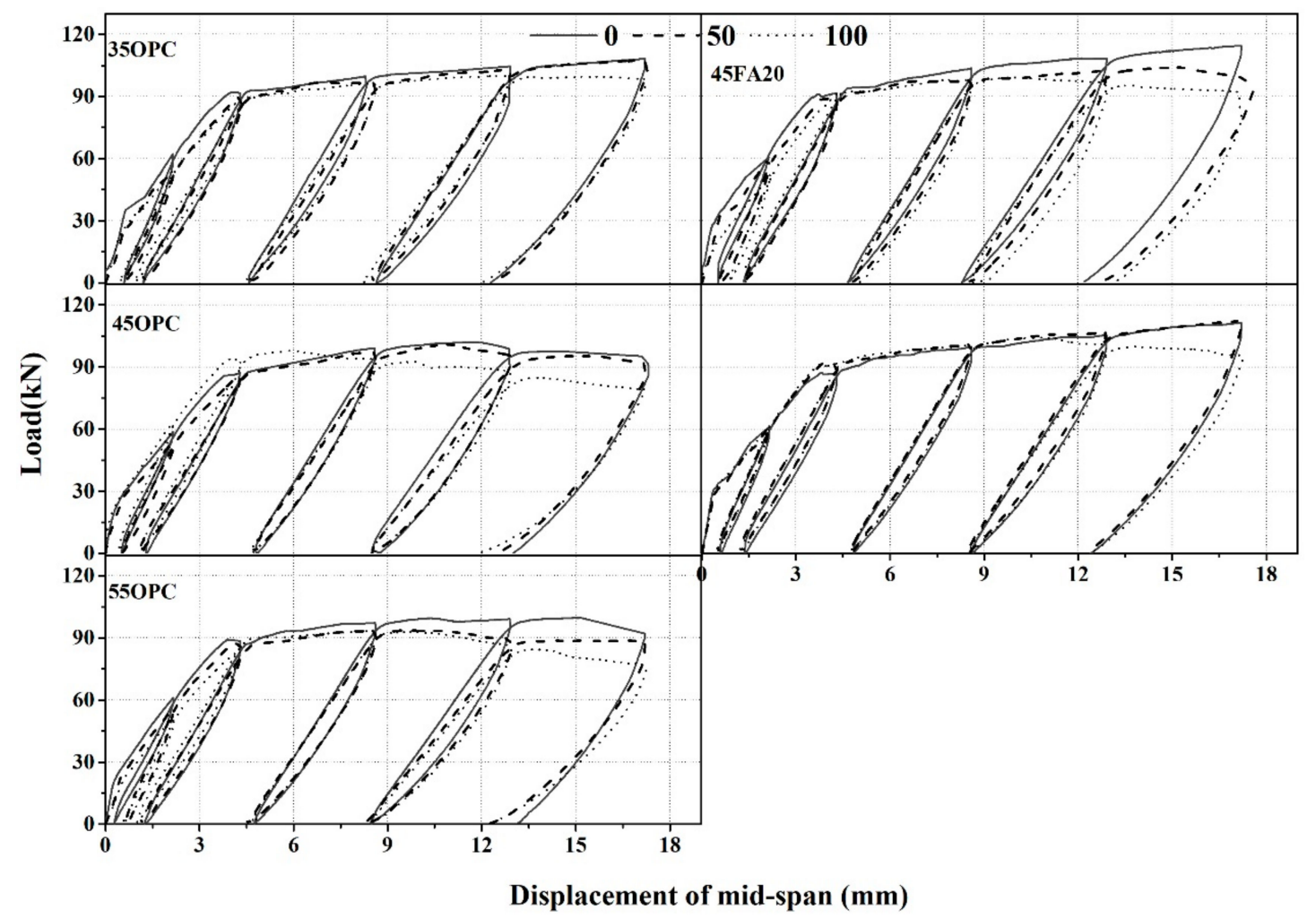

Figure 5. Load-displacement curves for RC beam.

Table 7. Experimental results of ductility index of RC member.

\begin{tabular}{|c|c|c|c|c|c|c|c|c|c|c|}
\hline \multicolumn{2}{|c|}{ Specimen ID } & \multicolumn{3}{|c|}{$35 \mathrm{OPC}$} & \multicolumn{3}{|c|}{$45 \mathrm{OPC}$} & \multicolumn{3}{|c|}{$55 \mathrm{OPC}$} \\
\hline $\mathrm{H}$ & & 0 & 50 & 100 & 0 & 50 & 100 & 0 & 50 & 100 \\
\hline \multirow{2}{*}{ Initial crack } & $P_{\mathrm{cr}}(\mathrm{kN})$ & 34.15 & 25.36 & 23.85 & 22.22 & 29.88 & 18.36 & 22.31 & 23.57 & 22.03 \\
\hline & $\Delta_{\mathrm{cr}}(\mathrm{mm})$ & 0.62 & 0.59 & 0.49 & 0.31 & 0.69 & 0.18 & 0.32 & 0.66 & 0.48 \\
\hline \multirow{2}{*}{ Yield Point } & $P_{\mathrm{y}}(\mathrm{kN})$ & 91.87 & 90.02 & 89.94 & 85.95 & 86.11 & 93.77 & 89.23 & 82.36 & 87.76 \\
\hline & $\Delta_{\mathrm{y}}(\mathrm{mm})$ & 4.00 & 4.30 & 4.58 & 3.83 & 4.28 & 3.96 & 3.91 & 4.13 & 4.43 \\
\hline \multirow{2}{*}{ Peak point } & $P_{\mathrm{u}}(\mathrm{kN})$ & 108.24 & 107.40 & 99.93 & 101.97 & 100.85 & 97.81 & 99.82 & 93.57 & 93.16 \\
\hline & $\Delta_{\mathrm{u}}(\mathrm{mm})$ & 17.19 & 17.19 & 12.57 & 11.74 & 10.98 & 5.92 & 15.13 & 8.46 & 8.33 \\
\hline \multicolumn{2}{|c|}{ Ductility Index } & 4.3 & 4.0 & 2.74 & 3.07 & 2.57 & 1.49 & 3.87 & 2.05 & 1.88 \\
\hline \multicolumn{2}{|c|}{ Specimen ID } & \multicolumn{3}{|c|}{ 45FA20 } & \multicolumn{3}{|c|}{ 45BFS50 } & & & \\
\hline \multicolumn{2}{|c|}{ H.R } & 0 & 50 & 100 & 0 & 50 & 100 & & & \\
\hline \multirow{2}{*}{ Initial crack } & $P_{\mathrm{cr}}(\mathrm{kN})$ & 27.72 & 31.26 & 25.07 & 33.58 & 31.15 & 28.73 & & & \\
\hline & $\Delta_{\mathrm{cr}}(\mathrm{mm})$ & 0.33 & 0.55 & 0.72 & 0.50 & 0.47 & 0.38 & & & \\
\hline \multirow{2}{*}{ Yield Point } & $P_{\mathrm{y}}(\mathrm{kN})$ & 91.49 & 89.79 & 91.16 & 87.13 & 91.95 & 91.12 & & & \\
\hline & $\Delta_{\mathrm{y}}(\mathrm{mm})$ & 4.31 & 3.95 & 3.72 & 3.8 & 3.88 & 3.73 & & & \\
\hline \multirow{2}{*}{ Peak point } & $P_{\mathrm{u}}(\mathrm{kN})$ & 114.51 & 103.99 & 99.21 & 111.38 & 112.38 & 104.25 & & & \\
\hline & $\Delta_{\mathrm{u}}(\mathrm{mm})$ & 17.11 & 15.10 & 9.95 & 17.2 & 17.2 & 10.9 & & & \\
\hline \multicolumn{2}{|c|}{ Ductility Index } & 4.46 & 3.82 & 2.67 & 4.53 & 4.43 & 2.92 & & & \\
\hline
\end{tabular}


According to ACI 363 [23], ductility is explained as a ratio of the deflection (or cross-section curvature) at the ultimate load to the deflection (or curvature) at the load producing yield of the reinforcement (Equation (1)).

$$
\mu=\Delta \mathrm{u} / \Delta \mathrm{y}
$$

where, $\mu$ is the ductility index; $\Delta \mathrm{u}$ is the beam deflection at the ultimate load; $\Delta \mathrm{y}$ is the beam deflection at the yield load of the RC member.

The ductility index is shown in Table 7. From the results, the ductility index of the RC members is affected significantly by the heavyweight waste glass substitution ratio. This implies that the increment of the substitution ratio of heavyweight waste glass in the RC member caused the reduced flexural ductility. As mentioned earlier, these phenomena were affected by the load capacity decrement at the large deformed stage. However, the ductility index of the RC members using heavyweight waste glass can be improved by a low water-binder ratio or mineral admixture.

\subsection{Bending Moment-Curvature Relationship}

The accurate determination of the bending moment-curvature curve of the RC members is a reliable indicator of the load capacity of the concrete structure. Therefore, the measured values from the concrete strain gauges and embedded rebar strain gauges were compared. Furthermore, the values of individual gauges were measured until their readings became unreliable owing to the cracking on the concrete surface. Figure 6 shows the applied bending moment-curvature curve at the mid-span of the RC members. The results demonstrate that the slopes of the moment-curvature were similar before the initial cracking occurred, and the flexural rigidity did not exhibit any difference. When the heavyweight waste glass is replaced with fine aggregate, however, the moment-curvature curves changed. Namely, the heavyweight waste glass substitution ratio did affect the flexural rigidity of the RC members.

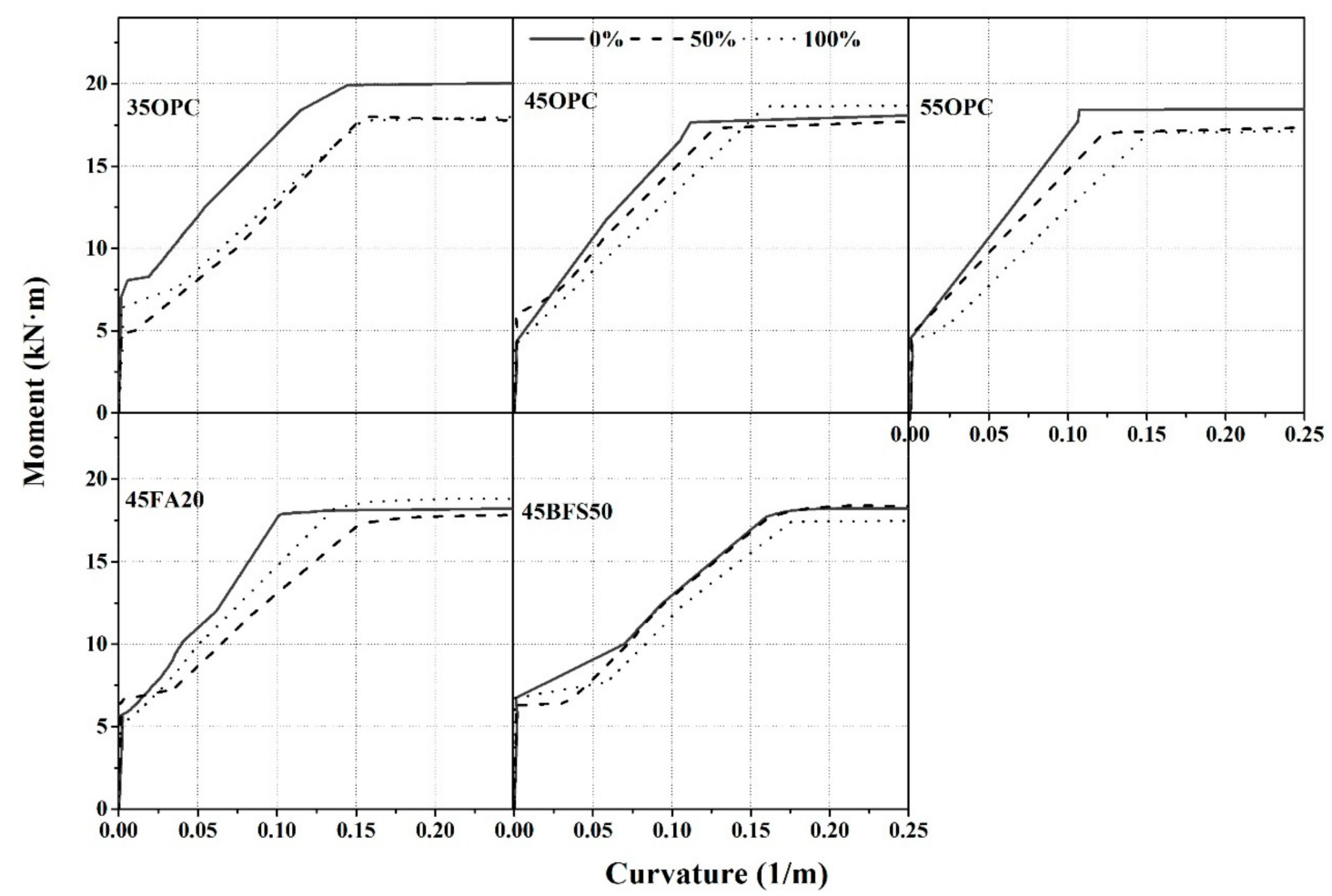

Figure 6. Moment-curvature curve for RC beam.

The bending moment of the initial cracking load corresponds to $3.6-6.8 \mathrm{kN} \cdot \mathrm{m}$ in all RC members. The moment-curvatures exhibited a nonlinear relationship after curvature of the first cracking load. 
In the nonlinear region, the curvature of the all the RC members increased suddenly. Conclusively, the moment-curvature curves of the RC member were reduced significantly when all the fine aggregate were replaced by heavyweight waste glass.

\subsection{Location of the Neutral Axis}

The experimental neutral axis depth of the RC member was obtained from the experimentally measured strain gauge values in the concrete and rebar. Figure 7 shows that the relationship between the moment and neutral axis depth determined until the rebar yielded. The results indicated that the neutral axis depth is immediately increased until $2-3 \mathrm{kN} \cdot \mathrm{m}$; subsequently, it converges to a constant value until the maximum moment is achieved. This trend is observed in all RC members, regardless of the water-binder ratio and heavyweight waste glass substitution ratio.

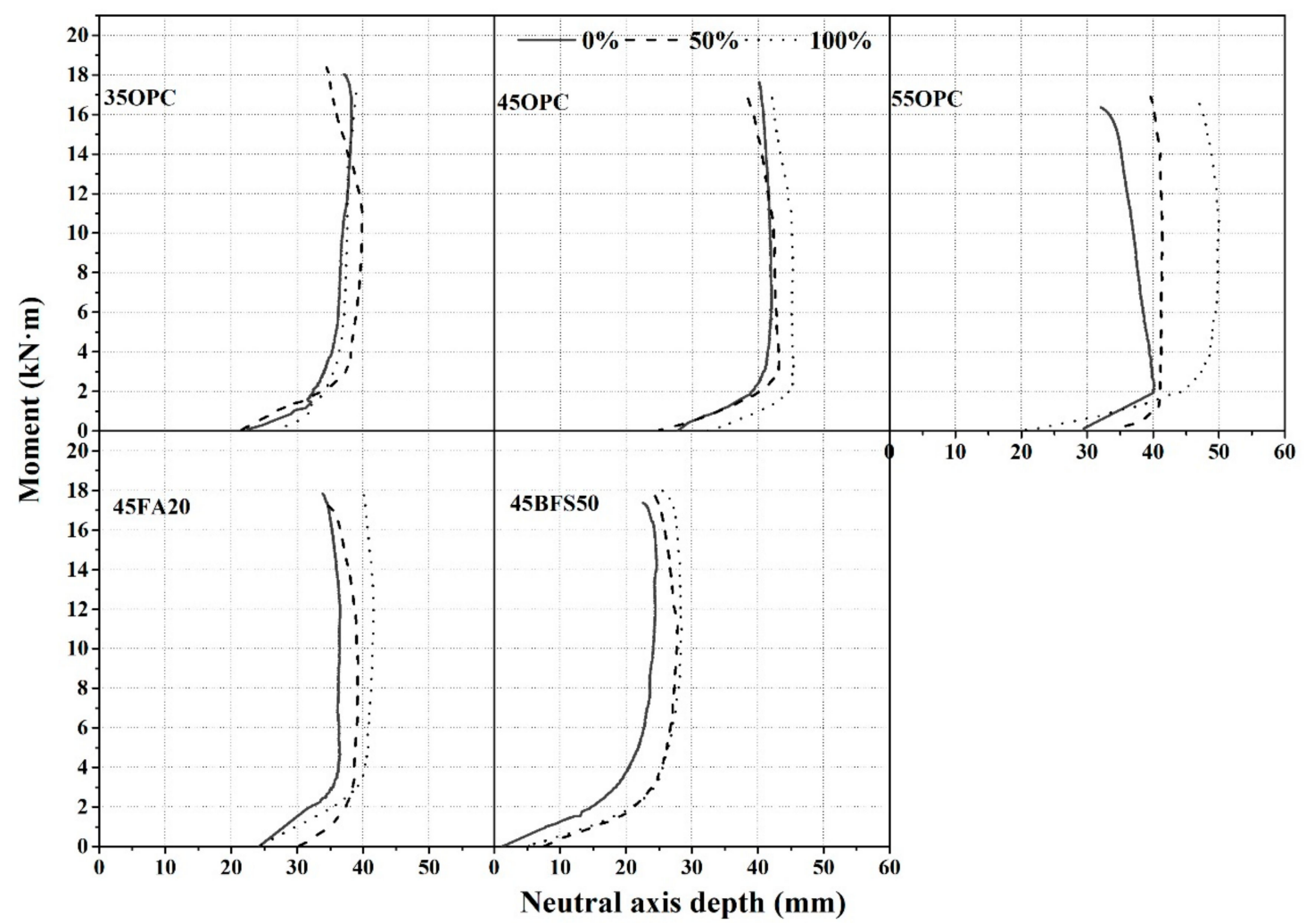

Figure 7. Location of the neutral axis depth.

However, the neutral axis depth is increased with heavyweight waste glass substitution ratio and water-binder ratio. Thus, the neutral axis depth of the rectangular stress block in the RC member is expected to increase with decreasing compressive strength. This trend is also shown in the RC member using the mineral admixture; however, the increase in the neutral axis depth could be alleviated. Therefore, to use the heavyweight waste glass as fine aggregate, the high compressive strength concrete is required.

\section{Conclusions}

The flexural behaviors of reinforced concrete member substituted heavyweight waste glass as fine aggregate under cyclic loading were examined. The conclusions obtained from this study are as follows:

(1) The heavyweight waste glass substitution ratio affected the crack occurrence patterns; further, when all the fine aggregate is replaced by heavyweight waste glass in the RC members, the possibility of sudden failure increased owing to concrete crushing in the compression zone. 
(2) The maximum load and ductility index of the RC members were affected by the heavyweight waste glass substitution ratio.

(3) The flexural rigidity of the RC member was reduced when the fine aggregate was replaced by heavyweight waste glass.

(4) In conclusion, the flexural behavior of RC members was affected by the heavyweight waste glass substitution ratio; however, the flexural performance could be improved using mineral admixture as a binder or a low water-binder ratio.

Author Contributions: All authors contributed to the experiments, analyses, and writing of the paper.

Funding: This research was supported by grant (18CTAP-C129756-02) from the Technology Advancement Research Program (TARP) funded by the Ministry of Land, Infrastructure and Transport of the Korean government.

Conflicts of Interest: The authors declare no conflict of interest.

\section{References}

1. Choi, S.Y.; Choi, Y.S.; Yang, E.I. Characteristics of volume change and heavy metal leaching in mortar specimens recycled heavyweight waste glass as fine aggregate. Constr. Build. Mater. 2018, 165, 424-433. [CrossRef]

2. Mehta, P.K.; Monteiro, P.J.M. Concrete: Microstructure, Properties, and Materials; McGraw-Hill: New York, NY, USA, 2014.

3. Chen, H.-J.; Wu, C.-H. Influence of Aggregate Gradation on the Engineering Properties of Lightweight Aggregate Concrete. Appl. Sci. 2018, 8, 1324. [CrossRef]

4. Kurda, R.; de Brito, J.; Silvestre, J. Combined Economic and Mechanical Performance Optimization of Recycled Aggregate Concrete with High Volume of Fly Ash. Appl. Sci. 2018, 8, 1189. [CrossRef]

5. Ogrodnik, P.; Szulej, J. The Assessment of Possibility of Using Sanitary Ceramic Waste as Concrete Aggregate-Determination of the Basic Material Characteristics. Appl. Sci. 2018, 8, 1205. [CrossRef]

6. Yao, Z.; Ling, T.C.; Sarker, P.K.; Su, W.; Liu, J.; Wu, W.; Tang, J. Recycling difficult-to-treat e-waste cathode-ray-tube glass as construction and building materials: A critical review. Renew. Sustain. Energy Rev. 2018, 81, 595-604. [CrossRef]

7. Disfani, M.M.; Arulrajah, A.; Bo, M.W.; Hankour, R. Recycled crushed glass in road work applications. Waste Manag. 2011, 31, 2341-2351. [CrossRef] [PubMed]

8. Kim, I.S.; Choi, S.Y.; Yang, E.I. Evaluation of durability of concrete substituted heavyweight waste glass as fine aggregate. Constr. Build. Mater. 2018, 184, 269-277. [CrossRef]

9. De Castro, S.; De Brito, J. Evaluation of the durability of concrete made with crushed glass aggregates. J. Clean. Prod. 2013, 41, 7-14. [CrossRef]

10. Ling, T.-C.; Poon, C.-S. Development of a method for recycling of CRT funnel glass. Environ. Technol. 2012, 33, 2531-2537. [CrossRef] [PubMed]

11. Choi, S.Y.; Choi, Y.S.; Won, M.S.; Yang, E.I. Evaluation on the Applicability of Heavy Weight Waste Glass as Fine Aggregate of Shielding Concrete. J. Korea Inst. Struct. Maint. Insp. 2015, 19, 101-108.

12. Choi, S.Y.; Choi, Y.S.; Yang, E.I. Effects of heavy weight waste glass recycled as fine aggregate on the mechanical properties of mortar specimens. Ann. Nucl. Energy 2017, 99, 372-382. [CrossRef]

13. Shao, Y.; Lefort, T.; Moras, S.; Rodriguez, D. Studies on concrete containing ground waste glass. Cem. Concr. Res. 2000, 30, 91-100. [CrossRef]

14. Shi, C.; Zheng, K. A review on the use of waste glasses in the production of cement and concrete. Resour. Conserv. Recycl. 2007, 52, 234-247. [CrossRef]

15. Tan, K.H.; Du, H. Use of waste glass as sand in mortar: Part I-Fresh, mechanical and durability properties. Cem. Concr. Compos. 2013, 35, 118-126. [CrossRef]

16. Wang, H.-Y. A study of the effects of LCD glass sand on the properties of concrete. Waste Manag. 2009, 29, 335-341. [CrossRef] [PubMed]

17. ASTM. Standard Test Method for Sieve Analysis of Fine and Coarse Aggregates; ASTM International: West Conshohocken, PA, USA, 2006.

18. ASTM. Standard Test Method for Compressive Strength of Cylindrical Concrete Specimens; ASTM International: West Conshohocken, PA, USA, 2005. 
19. ASTM. Standard Test Method for Static Modulus of Elasticity and Poisson's Ratio of Concrete in Compression; ASTM International: West Conshohocken, PA, USA, 2010.

20. Kim, Y.M.; Choi, S.Y.; Kim, I.S.; Yang, E.I. A study on the Mechanical Properties of Concrete using Electronic Waste as Fine Aggregate. J. Korea Inst. Struct. Maint. Insp. 2018, 22, 90-97.

21. Kou, S.C.; Poon, C.S. Properties of self-compacting concrete prepared with recycled glass aggregate. Cem. Concr. Compos. 2009, 31, 107-113. [CrossRef]

22. Lee, C.T. Production of alumino-borosilicate foamed glass body from waste LCD glass. J. Ind. Eng. Chem. 2013, 19, 1916-1925. [CrossRef]

23. American Concrete Institute. Report on High-Strength Concrete Reported; American Concrete Institute: Farmington Hills, MI, USA, 2010.

2018 by the authors. Licensee MDPI, Basel, Switzerland. This article is an open access article distributed under the terms and conditions of the Creative Commons Attribution (CC BY) license (http:/ / creativecommons.org/licenses/by/4.0/). 